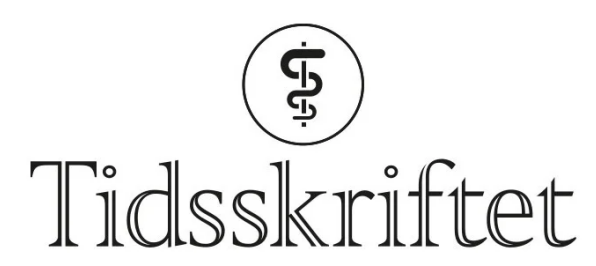

DEN NORSKE LEGEFORENING

\title{
Lovmessig seleksjonsmedisin i Forsvaret
}

KOMMENTAR

\section{ARNE JOHAN NORHEIM}

arne@avital.no

Arne Johan Norheim er sjef for Institutt for militær allmennhelse i Forsvarets sanitet, og leder for Forsvarets sanitets råd for seleksjonsmedisin

Forfatteren har ikke oppgitt noen interessekonflikter.

Forsvaret er en av de aller største aktørene når det gjelder medisinsk seleksjon i Norge ved å gjennomføre 150-200 ooo seleksjonsmedisinske skikkethetsvurderinger hvert år. Tidsskriftet presenterte tidligere i år en kronikk der det ble stilt spørsmål om hvorvidt seleksjonsmedisinsk praksis i Norge er lovstridig (1).

Forsvarets aktivitet styrer etter en rekke lovverk der særlig Forsvarsloven (므) og vernepliktsforskriften (3) regulerer seleksjon inn til alminnelig verneplikt. Forsvaret har også et omfattende internt bestemmelsesverk som styrer militærmedisinsk seleksjon. Mange av de seleksjonsmedisinske undersøkelsene i Forsvaret foregår i ungdomskullene hvor $90 \%$ selekteres bort fra utgangskohorten på om lag 6o ooo gutter og jenter. I tillegg skal alle av Forsvarets om lag 20 ooo stadig tjenestegjørende kvinner og menn jevnlig ha en medisinsk skikkethetsvurdering for internasjonal tjeneste. Det utføres også et betydelig antall medisinske funksjonsvurderinger for Forsvarets personell innen militær luftfart, militær sjøfart, samt en rekke høyst spesialiserte Forsvarsfunksjoner (ubåtredning, minedykking, baksete-F16, militær røykdykking, osv.). I tillegg gjøres alminnelige skikkethetsvurderinger, for eksempel ved helseattest for førerkort og sivile sjøattester.

Lov om likestilling og forbud mot diskriminering (4) som kom i 2017 forbyr diskriminering på grunn av funksjonsnedsettelse. Det er imidlertid i loven åpnet opp for lovlig forskjellsbehandling «når dette er nødvendig, og ikke representerer en uforholdsmessig inngripen for dem som utsettes for forskjellsbehandlingen». Det er forsvarets behov som styrer seleksjon inn til alminnelig verneplikt i Forsvaret. Enkelte sider ved medisinsk seleksjon i Forsvaret har vært gjenstand for vurdering i Likestillings- og diskrimineringsnemda. Det foreligger også rettspraksis som underbygger og gir støtte til hvordan medisinsk seleksjon praktiseres i Forsvaret. Internt i Forsvaret er det et system som gir adgang til å påklage skikkethetsvurderinger til legenemder. Leger som utnevnes til legenemder har som regel lang fartstid og mye seleksjonsmedisinsk erfaring, og flere leger er med å fatte vedtak i forsvarets klagenemder som følger forvaltningslovens bestemmelser. 
Kravene til likeverdig seleksjon er omfattende og sikkerhetssystemene som skal forhindre forskjellsbehandling er strenge. Forsvaret utøver seleksjon i tråd med gjeldende lover og regler for seleksjonsmedisinsk praksis.

\section{LITTERATUR}

1. Koefoed VF. Er seleksjonsmedisinsk praksis i Norge lovstridig? Tidsskr Nor Legeforen 2020;140. doi: 10.4045/tidsskr.19.o622. [PubMed][CrossRef]

2. Lov om verneplikt og tjeneste i Forsvaret m.m. (forsvarsloven). https://lovdata.no/dokument/NL//ov/2016-o8-12-77 Lest 18.8.2020.

3. Forskrift om verneplikt og heimevernstjeneste (vernepliktsforskriften). https://lovdata.no/dokument/SF/forskrift/2017-06-16-779 Lest 18.8.2020.

4. Lov om likestilling og forbud mot diskriminering (likestillings- og diskrimineringsloven). https://lovdata.no/dokument/NL/lov/2017-o6-16-51 Lest 18.8.2020.

Publisert: 28. september 2020. Tidsskr Nor Legeforen. DOI: 10.4045/tidsskr.20.0703

(C) Tidsskrift for Den norske legeforening 2023. Lastet ned fra tidsskriftet.no 26. april 2023. 